Discussion Paper No. 10-003

\title{
Female Labor Force Participation and the Big Five
}

Laura Wichert and Winfried Pohlmeier

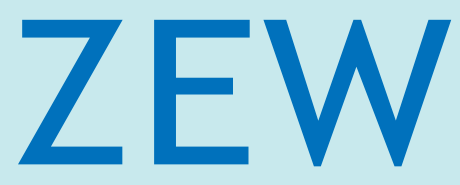

Zentrum für Europäische Wirtschaftsforschung $\mathrm{GmbH}$

Centre for European

Economic Research 
Discussion Paper No. 10-003

\title{
Female Labor Force Participation and the Big Five
}

\author{
Laura Wichert and Winfried Pohlmeier
}

Download this ZEW Discussion Paper from our ftp server:

ftp://ftp.zew.de/pub/zew-docs/dp/dp10003.pdf

Die Discussion Papers dienen einer möglichst schnellen Verbreitung von neueren Forschungsarbeiten des ZEW. Die Beiträge liegen in alleiniger Verantwortung der Autoren und stellen nicht notwendigerweise die Meinung des ZEW dar.

Discussion Papers are intended to make results of ZEW research promptly available to other economists in order to encourage discussion and suggestions for revisions. The authors are solely responsible for the contents which do not necessarily represent the opinion of the ZEW. 


\section{Non-technical Summary}

In this paper, we analyze the role of personality traits for female labor force participation. While research on the role of cognitive skills for individual labor market success has a long tradition in economics, comparatively little is known about the channels through which non-cognitive skills affect individual labor market behavior. However, we find strong evidence that aside from differences in cognitive skills, a large proportion of individual earnings differentials can be attributed to personality traits. Consequently, we expect two possible channels of personality traits having an influence on female labor force participation: First, personality traits that are favorable to higher wages might increase the probability of a women participating in the labor market simply because she faces higher wages. Second, there can also be a direct effect of personality traits if they influence preferences that determine labor force participation.

For our analysis, we use the Big Five Personality Concept of personal psychology that groups the personality facets of an individual into five personality domains: Extraversion, Agreeableness, Conscientiousness, Neuroticism and Openness to Experience. The data that we use is taken from the German Socio-Economic Panel (SOEP) that includes self reported measurements of the Big Five Traits additional to rich information about the socio-economic background as well as the employment history.

Our results show that personality traits play an important role for female labor force participation. In particular, we find that ignoring personality traits exaggerates the effect of education. We can show a strong positive effect of Extraversion and a strong negative effect of Agreeableness on wages. However, this effect does not carry through to the labor force participation since the wage elasticity for female labor supply is not significantly different from zero. Therefore, the effect of personality traits is largely a direct one. Conscientiousness has the largest positive impact, followed by Extraversion. High scores on Neuroticism and Openness lower the probability of a women participating in the labor market.

The study expands the understanding of the heterogeneity of individual decisions. We find strong evidence that the Big Five Personality Concept is closely related to preference parameters and that this effect is rather stable over different age groups compared to other socio-economic variables. However, future research has to shed more light on the role of personality traits for preference formation. Moreover, our results show the need to include personality traits also in other economic analyses since we do not expect that the impact of personality traits is only limited to the marginal rate of substitution between leisure and consumption. 


\section{Das Wichtigste in Kürze}

In diesem Beitrag untersuchen wir den Einfluss von Persönlichkeitsmerkmalen für die Erwerbsbeteiligung von Frauen. Während die Forschung zu Wirkungen von kognitiven Fähigkeiten für den individuellen Arbeitsmarkterfolg eine lange Tradition hat, gibt es bisher erst relativ wenige Erkenntnisse über die Wirkungsmechanismen von nicht-kognitiven Fähigkeiten für das individuelle Verhalten am Arbeitsmarkt. In unserem Beitrag finden wir Belege dafür, dass nicht-kognitive Fähigkeiten wesentlich dazu beitragen, individuelle Lohnunterschiede zu erklären. Die Persönlichkeit kann die Erwerbsbeteiligung von Frauen über zwei Kanale beeinflussen: Zum einen können bestimmte Persönlichkeitsmerkmale direkt zu höheren Löhnen führen, was wiederum die Wahrscheinlichkeit erhöht, dass Frauen mit diesen Persönlichkeitsmerkmalen erwerbstätig sind. Zum anderen gibt es die Möglichkeit, dass die Freizeitpräferenzen direkt von der Persönlichkeit beeinflusst werden.

In unserer Arbeit verwenden wir das Big Five-Konzept aus der Persönlichkeitspsychologie. Dieses gruppiert die verschiedenen Persönlichkeitsfacetten in fünf Hauptmerkmale: Extraversion, Verträglichkeit, Gewissenhaftigkeit, Neurotizismus und Offenheit für Erfahrungen. Die Daten stammen aus dem Sozio-Ökonomischen Panel (SOEP), das neben umfangreichen Informationen zum sozio-ökonomischen Hintergrund auch Informationen zu den Big Five-Merkmalen sowie der Erwerbshistorie bietet.

Die Ergebnisse zeigen, dass Persönlichkeit in der Entscheidung über die Erwerbsbeteiligung bei Frauen eine wesentliche Rolle spielt. Darüber hinaus können wir zeigen, dass der Einfluss von Bildung überschätzt wird, wenn Persönlichkeitsmerkmale in der Analyse fehlen. Der starke positive Effekt von Extraversion sowie der deutliche negative Effekt von Verträglichkeit für die Löhne spiegeln sich nicht direkt in der Gleichung für die Entscheidung zur Erwerbsbeteiligung wider, da der Lohn in dieser Entscheidung keine signifikante Rolle spielt. Einen direkten positiven Effekt haben die Gewissenhaftigkeit und die Extraversion, wobei Gewissenhaftigkeit die größte Rolle spielt. Frauen mit Neurotizismus beziehungsweise einer ausgeprägten Offenheit für Erfahrungen werden mit einer geringeren Wahrscheinlichkeit erwerbstätig.

Zusammenfassend tragen unsere Ergebnisse dazu bei, die Heterogenität der individuellen Arbeitsangebotsentscheidungen besser $\mathrm{zu}$ verstehen. Wir können zeigen, dass Persönlichkeitsmerkmale, gemessen mit dem Big Five-Konzept, die Freizeitpräferenzen beeinflussen. Im Unterschied zu anderen sozio-ökonomischen Faktoren erweist sich dieser Einfluss in verschiedenen Altersklassen relativ stabil. Für zukünftige Forschungen ergibt sich eine Reihe von Forschungsfragen. Insbesondere bedarf die Rolle der Persönlichkeit für die Entwicklung und Ausdifferenzierung von Präferenzen tiefer gehender Analysen. Unsere Ergebnisse verdeutlichen auch, dass die Rolle der Persönlichkeit für anderen ökonomischen Fragestellungen berücksichtig werden sollte, beispielsweise für Konsum- und Investitionsentscheidungen. 


\title{
Female Labor Force Participation and the Big Five
}

\author{
Laura Wichert* \\ University of Konstanz \\ Winfried Pohlmeier \\ University of Konstanz
}

This version: January 5, 2010

\begin{abstract}
This paper investigates the relationship between personality traits and female labor force participation. While research on the role of cognitive skills for individual labor market success has a long tradition in economics, comparatively little is known about the channels through which non-cognitive skills affect individual labor market behavior. There is striking evidence that personality traits play a major role in explaining individual differences in school attendance and school performance. However, comparatively little is known about how and which personality traits effect labor supply decisions. In this paper, we relate personality traits to preference parameters using a conventional structural framework of labor force participation. This allows us to separate the direct effects of personality traits affecting the individual participation decision through different individual preferences from the indirect effects through wages.
\end{abstract}

We can show that personality traits play an important role in the female labor force participation decision. The channels through which personality traits effect labor force participation are manifold and depend on the specific trait. Aggregation of traits to a single index is therefore a suboptimal strategy.

JEL classification: C35, J22, J24

PsycINFO classification: 2223, 3120

Keywords: personality traits, female labor supply, wages

\footnotetext{
*Corresponding author. Department of Economics, Box D124, University of Konstanz, 78457 Konstanz, Germany. Phone ++49-7531-88-5111, Fax -4450, email: Laura.Wichert@unikonstanz.de. Financial support by the Center for Psychoeconomics, the Center of Quantitative Methods and Survey Research (CMS) and the DFG research group Heterogeneity of Labor is gratefully acknowledged. A first draft of this paper was presented at the Inaugural Conference of the Leibniz Network "Non-Cognitive Skills: Acquisition and Economic Consequences", in Mannheim, May 2008. For helpful comments and discussions we would like to thank Angela Duckworth, Peter Gollwitzer, Jim Heckman, Lisa Green and Friedhelm Pfeiffer. The usual disclaimer applies.
} 


\section{Introduction}

This paper investigates the relationship between personality traits and female labor force participation. While research on the role of cognitive skills for individual labor market success has a long tradition in economics, comparatively little is known about the channels through which non-cognitive skills affect individual labor market behavior. There is striking evidence that personality traits play a major role in explaining individual differences in school attendance and school performance (e.g. Jacob (2002), Duckworth and Seligman (2005), Carneiro, Crawford, and Goodman (2007)). Bowles, Gintis, and Osborne (2001a) survey the early literature that relates personal characteristics to earnings. There is no longer any doubt that, aside from differences in cognitive skills, a large proportion of individual earnings differentials can be attributed to personality traits. Empirical evidence is provided, for example, for the US (Carneiro and Heckman (2002), Heckman, Stixrud, and Urzua (2006), Mueller and Plug (2006)), for Canada (Green and Riddell (2002)), for Sweden (Zetterberg (2005)), for the Netherlands (Nyhus and Pons (2005)) and Germany (Piatek and Pinger (2009), Heineck and Anger (2008) and Flossmann, Piatek, and Wichert (2007)). Although there is a growing literature attempting to synthesize the vast body of literature on personality traits and the economic literature on individual labor market performance, a large fraction of these studies focuse on earnings. Comparatively little is known about how and which personalty traits effect labor supply decisions.

The channels through which personality traits effect labor supply can be manifold. In a recent paper, Borghans, Duckworth, Heckman, and Ter Weel (2008) study the measurement of personality traits in psychology and their relationship to preference parameters in economics. They emphasize the link between personality measures and economic preference parameters such as time preferences, risk aversion, altruism and preferences for leisure. In this paper, we build on their idea and relate personality traits to preference parameters using a conventional structural framework of labor force participation. This allows us to separate the direct effects of personality traits affecting the individual participation decision based on different individual preferences from the indirect effects of wages and / or educational attainment. Empirical support for our strategy is given by the study by Flossmann, Piatek, and Wichert (2007). Interestingly, they find a rather weak direct effect of non-cognitive skills on female wages compared to the effect for males, suggesting that for females, 
given their educational attainment and occupational choices, much of the skill effects operate indirectly.

By focusing on the effects of non-cognitive skills on labor supply, our study also relates to the literature on intergenerational transmission of non-cognitive skills. While there is large body of literature in psychology and economics on the effects of mothers' employment patterns on child development (e.g. Bernal and Keane (2006), Gregg, Washbrook, Propper, and Burgess (2005), Harvey (1999) Hill, Waldvogel, Brooks-Gunn, and Han (2005), Ruhm (2004)), little is known about the transmission of personalty traits of parents to their children and how the labor supply decision of the mother and the decision of external child care interact with the skill acquisition process. Tavares (2008) finds that personality traits play an important role in the timing of childbearing. Since female labor force participation is closely related to the decision about having children, our results also contribute to this research field.

Disentangling the effects of personalty traits on labor force participation is not trivial and requires strong identifying restrictions. Here, we follow a rigorous structural approach by estimating a structural participation equation which allows us to interpret the estimated effects of personality traits in terms of preference parameters.

Our taxonomy of personality is based on the concept of the Big Five personality scale which maps the multidimensional facets of personality into five distinct factors (Costa and McCrae $(1995,1999)$ ). The cross-section of married women and cohabiting women in Germany our empirical study is based on is taken from the 2005 wave of the German Socio-Economic Panel (SOEP), which contains fifteen qualitative self-assessments on the Big Five.

The outline of the paper is as follows. Section 2 reviews the Big Five taxonomy and its relevance to the labor force participation decision. In Section 3, we work out our econometric approach, where we relate the Big Five to preference parameters of the labor supply function. Section 4 contains the relevant information on our sample, while in Section 5 the empirical findings are presented. Section 6 concludes and provides an outlook on future research. 


\section{The Big Five Personality Traits}

In the subsequent analysis, we use the Big Five Personality Concept to image the various dimensions of personal traits. This concept, widely used in psychology, provides a solution to the problem of how to measure the complex structure of the personality of an individual and offers a consensus for researchers from different fields that are researching personality (John and Srivastava (1999)). The Big Five Model states that the personality of an individual can be grouped into five personality domains which can be each divided into six subgroups, the facets. Table 1 summarizes the Big Five Personality Traits and the corresponding facets.

Table 1: Description of the five main personality traits

\begin{tabular}{ll}
\hline \hline Extraversion: & $\begin{array}{l}\text { Friendliness, Gregariousness, Assertiveness, } \\
\text { Activity Level, Excitement-Seeking, Cheerfulness }\end{array}$ \\
\hline Agreeableness: & Trust, Morality, Altruism, Cooperation, \\
& Modesty, Sympathy \\
\hline Conscientiousness: & Self-Efficacy, Orderliness, Dutifulness, Achievement-Striving, \\
& Self-Discipline, Cautiousness \\
\hline Neuroticism: & Anxiety, Anger, Depression, Self-Consciousness, \\
& Immoderation, Vulnerability \\
\hline Openness: & Imagination, Artistic Interest, Emotionality, \\
& Adventurousness, Intellect, Liberalism \\
\hline \hline
\end{tabular}

See: Dehne and Schupp (2007) and Costa and McCrae (1992)

In general, we can distinguish two types of traits: Extraversion and Agreeableness describe the interindividual behavior, meaning that these traits describe how an individual interacts with others. On the other hand, Conscientiousness, Neuroticism, and Openness to Experience deal with the intraindividual habitude of a person. These traits characterize how an individual deals with intellectual and emotional tasks.

The trait Extraversion captures how an individual behaves among others. A person with a high level of extraversion is thus friendly, likes having company, knows how to prevail, is active, likes impulses from new experiences and has positive emotions. Seibert and Kraimer (1995) find that extraverted people earn more, have more success in their working career and are more satisfied with their private and working lives. We would therefore expect that Extraversion has a positive effect on labor 
force participation. However, Fahr and Kusche (2008) find a positive relationship between Extraversion and absenteeism for females. They argue that extraverted individuals value additional leisure time more to recover from their work environment and to meet with friends and family.

A person with a high score on the trait Agreeableness is considered to be selfless, helpful, and cares for others. Less agreeable individuals, on the other hand, are egoistical, selfish and uncooperative. Erdheim, Wang, and Zickar (2006) find a positive relationship between Agreeableness and normative commitment. However, Seibert and Kraimer (1995) show that persons with a high score on Agreeableness have lower job satisfaction. Fahr and Kusche (2008) find a negative influence of Agreeableness on absenteeism for males and no effect for females. In the light of the present analysis, we could expect that agreeable women tend to be altruistic towards their spouse and children and therefore resign from their own career ambitions.

Conscientiousness describes the way how people deal with problems. Conscientious people show a high level of responsibility for themselves as well as for others. Furthermore, they are organized, hard working and ambitious. Barrick and Mount (1991) show a positive effect of Conscientiousness on job performance, which leads us to expect a positive effect on the likelihood of participating in the labor force as well.

The domain Neuroticism characterizes how people experience strong positive and negative emotions, i.e. their emotional stability. Individuals with a high score on Neuroticism cannot cope with stress and get frustrated and nervous easily. In contrast to the facets of the other Big Five Traits, the facets of the domain Neuroticism have a negative connotation. Therefore, a very strong markedness of Neuroticism has a negative connotation while a high score on the other traits is socially desirable. Vearing and Mak (2007) find that a high score on Neuroticism leads to a high work commitment (even an over-commitment) on the one hand, but that this can often lead to physical and mental illness on the other hand as well. We hypothesize that the hurdle to start working is higher for neurotic women and that they are thus less likely to participate in the labor force.

The personality trait Openness to Experience describes how needy somebody is for changes, novelty, and complexity. The dimension 'Experience' includes the aspects 
fantasy, aesthetics, feelings, ideas, as well as values. Several facets of this domain are very abstract and difficult to operationalize. A highly open person may enjoy a complex job but may also cherish self-determination. Hence, it is difficult to estimate whether or not this domain influences the probability of a women taking part in the labor market. Fahr and Kusche (2008) do not find any effect of Openness to Experience on job absenteeism.

\section{Empirical Approach}

In our empirical strategy, we relate the Big Five personality traits to the individual preference parameters of a labor supply equation, which can be derived from an life-cycle labor supply decision sticking to the traditional assumption of explicit additivity of the intertemporal utility function and intertemporal additivity of the budget constraint. For the within-period preference function, we postulate parallel preferences of the form: ${ }^{1}$

$$
U_{i t}\left(C_{i t}, L_{i t}\right)=G_{i t}\left(C_{i t}+V_{i t}\left(L_{i t}\right)\right)
$$

where $C$ is consumption, $L$ is leisure. $G_{i t}(\cdot)$ represents an increasing function. For parallel preferences labor supply is independent of the marginal utility of wealth, i.e. the Frisch labor supply equation coincides with the Marshallian and the Hicksian form (See Koebel, Laisney, Pohlmeier, and Staat (2008) for details). In the context of our analysis, this admittedly restrictive parametric specification is a useful starting point because labor supply is independent of the time preference parameter so that personality traits enter the labor supply equation only through the parameters of the preference function (3.1). Therefore, the model is consistent with both hyperbolic discounting, as suggested by experimental evidence from psychology (e.g. Ainslie and Monterosso (2004), Rachlin (2006)), and exponential discounting, as the dominant specification strategy in economics. A more flexible preference function would cause an additional identification problem because personality traits affecting preferences for leisure and those affecting time preferences would have to be identified by additional functional form assumptions. A similar argument holds for risk preference (Green and Myerson (2004)). In a general framework, separate preference parameters for risk aversion and the consumption-leisure trade-off cannot be

\footnotetext{
${ }^{1}$ See König, Laisney, Lechner, and Pohlmeier (1995) and Laisney, Lechner, van Soest, and Wagenhals (1993) for two female labor supply studies using this preference function.
} 
identified without additional functional form assumptions. If the individual overall preference for risk is reflected by the curvature of $G_{i t}(\cdot)$, the curvature of $V_{i t}(\cdot)$ may be interpreted as representing predominantly the preferences with respect to the consumption-leisure trade-off.

Assuming a Box-Cox specification $V_{i t}\left(L_{i t}\right)=\gamma_{i t}\left(L^{\alpha_{L}}-1\right) / \alpha_{L}$ with $0<\alpha_{L}<1$ yields a leisure demand equation of the form

$$
\ln L_{i t}=\frac{\ln \gamma_{i t}}{1-\alpha_{L}}-\frac{1}{1-\alpha_{L}} \ln W_{i t}
$$

where $W_{i t}$ is the wage. Note that the labor supply equation is log linear in the preference parameter $\gamma$, which determines the marginal rate of substitution between leisure and consumption. This parameter is a natural candidate to link personalty traits $P_{i}$ with labor supply parameters. Let $\gamma$ be given by the second order approximation

$\ln \gamma_{i t}=\gamma_{0}(t)+\gamma_{z}(t) Z_{i t}+\gamma_{p}(t) \ln P_{i}+\gamma_{z z}(t) Z_{i t}^{2}+\gamma_{p p}(t)\left(\ln P_{i}\right)^{2}+\gamma_{z p}(t) Z_{i t} \ln P_{i}+\nu_{i t}$,

where $Z_{i t}$ denotes other observable socio-economic factors capturing individual heterogeneity in the marginal rate of substitution between consumption and leisure, while the error term $\nu_{i t}$ captures unobserved heterogeneity.

Note that the preferences are allowed to vary over the life-cycle. In particular, we want to allow for life-cycle context related effects of personal factors (personality traits, age family characteristics, such as, age of children) to effect the labor force participation decision. Borghans, Duckworth, Heckman, and Ter Weel (2008) review empirical evidence concluding that traits are sufficiently stable across situations to support the claim that traits exist. Traits, however, evolve over the life-cycle and their manifestation is contextual dependent. To our knowledge, little is known about traits with relation to the labor force participation decision. Obviously, our approach implicitly assumes that traits are sufficiently stable over the life-cycle such that individual responses on questions reflecting personality traits as provided by the SOEP can be treated as proxies for unobserved personalty traits. The question whether or not this assumption about the stability of the traits is valid, has been widely discussed in the literature (see e.g. Conley (1985), Gustavsson, Weinryb, Gransson, Pedersen, and Asberg (1997), Costa, Herbst, McCrae, and Siegler (2000), 
Caspi and Roberts (2001), Srivastava, John, Gosling, and Potter (2003) and Costa and McCrae (2006)). Although the authors admit that there can be small changes in some of the personality traits during the life cycle, they all conclude that the traits can be seen as mostly stable after the age of 30 .

\section{The Data}

Our sample is taken from the 2005 wave of the German Socio-Economic Panel (SOEP). It contains women living together with their partner. We do not condition on being married, i.e. we look at married couples and cohabiting couples, but we include a dummy for being married in our regression analysis. Women with partners who are not covered by the survey are excluded from our analysis. Furthermore, we restrict our analysis to women in the prime working years between age 25 to 54 . This is done to avoid issues such as school and/or university enrollment as well as early retirement. Table A1 in Appendix A contains the definitions of the variables used in the following analysis. Observations with missing information on one of the characteristics are excluded from the sample. This leaves us 3,390 observations for 2005. The summary statistics of the overall sample and by participation status are displayed in Table A2.

Our variable of interest is PARTIC, a dummy variable indicating whether or not a woman participates in the labor market. We define this variable so as to come as close as possible to the notional participation concept by counting those as participating who are in fact participating in the labor force and those who intend to participate. Thus, we also consider a woman as participating if she is marginally or irregularly employed and looking for a full- or part-time employment at the same time. In addition, women in maternity protection ("Mutterschutz") or on parental leave ("Erziehungsurlaub") are also counted as participating.

Finally, women who are officially registered at the Employment Office as being unemployed and intend to engage in paid part- or full-time employment as soon as possible and have been actively looking for work within the last four weeks are also treated as participating. Table 2 shows the composition of our sample with respect to the employment status. All states except the first one are treated as participation states, which corresponds to a labor force participation rate of $75.2 \%$. The share of women working either full- or part-time is about $62.8 \%$, this seems to be reasonable 
and representative for this population. Merz (2005) presents comparable results for the women's employment-to-population ratio in Germany in $2000.12 .2 \%$ of the women in the sample are counted as participating in the labor market even though they are not gainfully employed at the time.

Table 2: Employment status of the women in the sample

\begin{tabular}{l|rr}
\hline \hline Employment status & Nobs. & Percentage \\
\hline Not participating & 839 & 24.8 \\
Full-time employed & 1,125 & 33.2 \\
Part-time employed & 1,002 & 29.6 \\
Marginally employed and looking for a regular job & 7 & 0.2 \\
Maternity protection & 84 & 2.5 \\
Parental leave & 210 & 6.1 \\
Registered unemployed and willing to work & 123 & 3.6 \\
\hline Total & 3,390 & 100.0 \\
\hline \hline
\end{tabular}

SOEP, Wave 2005, Number of obs. $=3,389$

One third of the women in our sample are full-time and $29 \%$ part-time employed. Overall, $84 \%$ have at least one child, $18 \%$ of the women in our sample have three or more children. Comparing the two groups of participating women on the one hand and those not participating in the labor force on the other hand shows that in the former group, $81 \%$ of the women have at least one child, while this share is $93 \%$ in the latter group. Table A3 gives more details about the children situation of the women in the sample. Another important difference between the two groups is the education level: one fourth of the non-participating women did not exceed the lowest vocational degree, this share is only $10 \%$ in the participating group. Compared with this, $25 \%$ of the participating women reached the highest education level, that is an university degree, while only every tenth women in the other group attained this level. Thus, the average education level in the group of participating women is higher.

The Big Five Personality Traits that we use as a proxy for non-cognitive skills in this paper is a psychological concept used to describe and study personality. In the 2005 wave of the SOEP, this concept was first introduced in the panel. Originally, the Big Five is measured using a long questionnaire. Since this is not tractable in the SOEP, a short item scale, the BFI-S, with 15 instead of originally 25 items has been developed (see Gerlitz and Schupp (2005) for a detailed description). Dehne and 
Schupp (2007) review the Big Five measurement in the SOEP and show its validity and reliability. The BFI-S consists of 15 statements that have to be assessed by the respondents on a 7-tier Likert-Scale, 1 meaning "I strongly disagree" and 7 meaning "I strongly agree". Each three of these statements belongs to one trait, the ordering of the statements during the interview is not clustered. Each statement can be classified into one of two possible groups: either an agreement with the statement belongs to a strong markedness of the trait in question $(+)$; or an agreement with the statement can be seen as a sign for a strong opposition to the trait (-). Table 3 illustrates the measurement of the Big Five Index in the SOEP.

Table 3: The Big Five Personality Traits in the SOEP (2005)

\begin{tabular}{ll} 
"I see myself as someone who ... & \\
\hline \hline Extraversion: & $\ldots$ is communicative, talkative $(+)$ \\
& $\ldots$ is outgoing, sociable $(+)$ \\
& $\ldots$ is reserved $(-)$ \\
\hline Agreeableness: & $\ldots$ has a forgiving nature $(+)$ \\
& $\ldots$ is considerate and kind to others $(+)$ \\
& $\ldots$ is sometimes somewhat rude to others $(-)$ \\
\hline Conscientiousness: & $\ldots$ does a thorough job $(+)$ \\
& $\ldots$ does things effectively and efficiently $(+)$ \\
& $\ldots$ tends to be lazy $(-)$ \\
Neuroticism: & $\ldots$ is relaxed, handles stress well $(-)$ \\
& $\ldots$ gets nervous easily $(+)$ \\
& $\ldots$ worries a lot $(+)$ \\
\hline Openness: & $\ldots$ is original, comes up with new ideas $(+)$ \\
& $\ldots$ has an active imagination $(+)$ \\
& $\ldots$ values artistic experiences $(+)$
\end{tabular}

Table A4 in Appendix A displays the correlation between the different personality traits of the Big Five Concept, where all correlation coefficients are significantly different from zero $(p<0.01)$. All traits except Neuroticism show positive correlation coefficients. Therefore, the measurement of the trait Neuroticism should be treated inversely to the others. The opposite of Neuroticism is often referred to as Emotional Stability. In order to construct a measure for each trait, we add up the answers of the three questions for each trait, where "I strongly disagree" is worth one point and "I strongly agree" seven points in a positive question, in a negative question, we give one point for "I strongly agree" and seven for "I strongly disagree". The points of the 
three questions are added to get a single score for each trait, ranging from 3 to 21 . We also construct a unidimensional Big Five-Index as the sum of the five traits. Here, we have to take into account that Neuroticism has a negative weight, we therefore recode this variable and use Emotional Stability ${ }^{2}$ instead. The Big Five-Index is then given by BigFive - Index $=C O N S C+O P E N+E X T+A G R E E+E M O S T A B$. The scores for each trait as well as the Big Five-Index are standardized with mean set to zero and variance equal to one for the following analysis.

In order to compare the relevance of the Big Five for the two groups in Table A2, we perform a t-test to check whether differences in the Big Five scores between participating and non participating women exist: For the traits Extraversion, Neuroticism and Conscientiousness, we find that the mean difference is highly significant $(p<0.01)$. Moreover, we can say that the mean score in the group of participating women is significantly higher for the traits Extraversion and Conscientiousness whereas the score for Neuroticism is significantly smaller in this group. The traits Openness to Experience and Agreeableness do not show a significant difference $(p>0.10)$. The overall Big Five-Index gives a significantly higher score in the group of the participating women $(p<0.01)$. We therefore observe higher noncognitive skills in women that participate in the labor force. Figure B1 in Appendix $\mathrm{B}$ illustrates the distribution of the five traits and the Big Five-Index by participating status. In the following section, we will estimate whether these observed differences in the personality traits influence women in their decision regarding labor force participation.

A final issue that need to be addressed is the question of whether or not personality traits are stable over time and wether personality traits and their self assessments are influenced by previous labor market participation. If the traits are influenced by changes in the labor force participation status and dynamic feedbacks occur causal effects are difficult to identify. Using information on the previous participation history we provide some evidence that the assumption of constant personality traits is not too unrealistic.

\footnotetext{
${ }^{2} E M O S T A B=24-N E U$
} 


\section{$5 \quad$ Empirical Results}

A number of empirical studies using the Rotter scale (Flossmann, Piatek, and Wichert (2007)), the Big Five concept (e.g. Mueller and Plug (2006), Nyhus and Pons (2005)) or both ((Heineck and Anger (2008)) show that non-cognitive skills have some explanatory power in explaining individual wage differences. Bowles, Gintis, and Osborne (2001b) argue that theses skills contribute to production by providing a service that appears as an argument in the production function. In the light of a principle agent problem, non-cognitive skills as an argument of the preference function are incentive enhancing, which implies that an employee's work ceteris paribus is more productive at every wage rate. Thus, employers are willing to set wages higher for those workers who reveal such incentive-enhancing preferences. The evidence though is not too striking if the wage equation includes control variables for human capital and/or cognitive skills.

Since there is no generally agreed-upon estimation strategy for the estimation of a labor force participation equation, we follow a simple two-stage approach where wages are imputed from a Becker-Mincer type earnings function and account for sample selectivity via a Heckman type of control function. The selection equation we use is a reduced form specification of the participation equation. It uses information on the proximity of the parents' home ( $\left.P A R_{-} C O L S E\right)$ and the woman's personal assessment of the child care conditions (NOT_SATISFIED) as proxies for the time costs and monetary cost of labor force participation, which do not enter the wage equation and are not element of the structural participation equation. A similar approach is taken by Heim (2007) in his labor supply study for the US and described there in more detail.

Table 4 contains the least squares estimates of the wage equation for the sample of working women which gives a first impression of the role of personality traits for wage determination. We use the natural log of the hourly net wage as the dependent variable. Since this information is not directly available in the SOEP, we compute the wage from information on the monthly net wage and the agreed upon work time per week ${ }^{3}$. Moreover, only women are included in the sample who work part- or full-time and report a monthly net wage of at least 400 Euro. Observations on ages for women who are marginally or irregularly employed are excluded from our study,

\footnotetext{
${ }^{3}$ The hourly wage was calculated by HOUR_WAGE $=\frac{\text { monthly wage }}{\text { (weekly working hours }) * \frac{52}{12}}$.
} 
because we think that this information is not reliable because the hourly wage rates for these observations suffer from a serious bias.

Inclusion of the Big Five as additional controls does not improve the explanatory power of the wage equation in terms of the adjusted $R^{2}$ (column 1 and 2) substantially. The joint exclusion of the five regressors is rejected by the F-statistics $(p<0.01)$, only Extraversion and Agreeableness turn out to have a significant effect on wages $(p<0.01)$. As expected, Extraversion has a positive effect on wages, while for Agreeableness we observe a negative one. Since these two personal traits relate to interindividual behavior, we can state that the interindividual traits seem to matter more for wages than the intraindividual skills described by the three other traits. Our result for Agreeableness supports the notion that agreeable persons are weaker wage negotiators and may have a more egalitarian attitude towards payment. But the negative sign may also reflect job choice aspects. More agreeable employees may be found in low wage sectors, in particular in the service sector or in health care services. Our finding is somewhat more pronounced than comparable findings by Nyhus and Pons (2005) for the Netherlands, who find a significant negative coefficient at the 10 percent level, while Mueller and Plug (2006) find no significant effect of this trait at all using US data. Neither Mueller and Plug (2006) nor Nyhus and Pons (2005) find a significant influence of Extraversion on female wages. The latter find a positive effect of emotional stability on wages, which would correspond to a negative effect of Neuroticism on wages in our model that we cannot confirm. Moreover, a comparison of the augmented wage equation (column 2) with the standard wage equation (column 1) reveals that the Big Five regressors are close to being orthogonal to the included explanatory variables because the coefficient estimates change only slightly when we augment the wage equation by the Big Five regressors. 
Table 4: Estimates of Wage Equation

\begin{tabular}{|c|c|c|c|c|c|}
\hline & $\begin{array}{l}\text { without } \\
\text { Big } 5\end{array}$ & $\begin{array}{l}\text { with } \\
\text { Big } 5\end{array}$ & $\begin{array}{l}\text { Big 5-Index } \\
2005\end{array}$ & $\begin{array}{c}\text { without } \\
\text { Education }\end{array}$ & $\begin{array}{c}\text { Cross-section } \\
2007\end{array}$ \\
\hline EAST & $\begin{array}{c}-0.2303 \\
(0.00)\end{array}$ & $\begin{array}{c}-0.2289 \\
(0.00)\end{array}$ & $\begin{array}{c}-0.2303 \\
(0.00)\end{array}$ & $\begin{array}{c}-0.1632 \\
(0.00)\end{array}$ & $\begin{array}{c}-0.2328 \\
(0.00)\end{array}$ \\
\hline AGE & $\begin{array}{c}0.0128 \\
(0.19)\end{array}$ & $\begin{array}{c}0.0107 \\
(0.28)\end{array}$ & $\begin{array}{c}0.0127 \\
(0.19)\end{array}$ & $\begin{array}{c}0.0130 \\
(0.24)\end{array}$ & $\begin{array}{c}0.0018 \\
(0.87)\end{array}$ \\
\hline$A G E^{2} * 0.01$ & $\begin{array}{c}-0.0085 \\
(0.49)\end{array}$ & $\begin{array}{c}-0.0055 \\
(0.65)\end{array}$ & $\begin{array}{c}-0.0084 \\
(0.49)\end{array}$ & $\begin{array}{c}-0.0058 \\
(0.67)\end{array}$ & $\begin{array}{l}0.0037 \\
(0.79)\end{array}$ \\
\hline GERMAN & $\begin{array}{c}0.1567 \\
(0.00)\end{array}$ & $\begin{array}{c}0.1531 \\
(0.00)\end{array}$ & $\begin{array}{c}0.1568 \\
(0.00)\end{array}$ & $\begin{array}{c}0.2320 \\
(0.00)\end{array}$ & $\begin{array}{c}0.1564 \\
(0.00)\end{array}$ \\
\hline MID_VOC & $\begin{array}{c}0.0569 \\
(0.04)\end{array}$ & $\begin{array}{c}0.0568 \\
(0.04)\end{array}$ & $\begin{array}{c}0.0567 \\
(0.04)\end{array}$ & & $\begin{array}{c}0.0487 \\
(0.14)\end{array}$ \\
\hline HIGH_VOC & $\begin{array}{c}0.1734 \\
(0.00)\end{array}$ & $\begin{array}{c}0.1726 \\
(0.00)\end{array}$ & $\begin{array}{c}0.1732 \\
(0.00)\end{array}$ & & $\begin{array}{c}0.1684 \\
(0.00)\end{array}$ \\
\hline HIGH_EDU & $\begin{array}{c}0.4735 \\
(0.00)\end{array}$ & $\begin{array}{r}0.4717 \\
(0.00)\end{array}$ & $\begin{array}{c}0.4733 \\
(0.00)\end{array}$ & & $\begin{array}{c}0.4691 \\
(0.00)\end{array}$ \\
\hline CONST & $\begin{array}{l}1.5094 \\
(0.00)\end{array}$ & $\begin{array}{l}1.5499 \\
(0.00)\end{array}$ & $\begin{array}{l}1.5104 \\
(0.00)\end{array}$ & $\begin{array}{l}1.5578 \\
(0.00)\end{array}$ & $\begin{array}{l}1.7818 \\
(0.00)\end{array}$ \\
\hline EXT (2005) & & $\begin{array}{c}0.0262 \\
(0.00)\end{array}$ & & $\begin{array}{c}0.0152 \\
(0.12)\end{array}$ & $\begin{array}{c}0.0206 \\
(0.04)\end{array}$ \\
\hline AGREE (2005) & & $\begin{array}{c}-0.0247 \\
(0.00)\end{array}$ & & $\begin{array}{c}-0.0290 \\
(0.00)\end{array}$ & $\begin{array}{c}-0.0181 \\
(0.06)\end{array}$ \\
\hline CONSC (2005) & & $\begin{array}{c}-0.0083 \\
(0.42)\end{array}$ & & $\begin{array}{c}-0.0340 \\
(0.00)\end{array}$ & $\begin{array}{c}-0.0113 \\
(0.32)\end{array}$ \\
\hline NEU (2005) & & $\begin{array}{c}-0.0040 \\
(0.63)\end{array}$ & & $\begin{array}{c}-0.0162 \\
(0.08)\end{array}$ & $\begin{array}{c}-0.0134 \\
(0.15)\end{array}$ \\
\hline OPEN (2005) & & $\begin{array}{c}-0.0054 \\
(0.55)\end{array}$ & & $\begin{array}{c}0.0264 \\
(0.01)\end{array}$ & $\begin{array}{c}0.0045 \\
(0.66)\end{array}$ \\
\hline $\begin{array}{l}\text { Big Five Index } \\
(2005)\end{array}$ & & & $\begin{array}{c}0.0011 \\
(0.89) \\
\end{array}$ & & \\
\hline $\begin{array}{l}\text { Nobs. } \\
\bar{R}^{2} \\
F_{(5)} \text { Big } 5 \\
\end{array}$ & $\begin{array}{c}2,127 \\
0.2572\end{array}$ & $\begin{array}{c}2,127 \\
0.2622 \\
3.82 \\
\end{array}$ & $\begin{array}{c}2,127 \\
0.2569\end{array}$ & $\begin{array}{c}2,127 \\
0.0802 \\
6.99 \\
\end{array}$ & $\begin{array}{c}1,668 \\
0.2620 \\
2.47 \\
\end{array}$ \\
\hline
\end{tabular}

Least squares estimates based on part- or full-time employed women without

selectivity correction, p-values in parenthesis. Dependent variable: log hourly wages.

Standardized values of the Big Five Traits.

In column 3 of Table 4 we also present the results when including the Big Five-Index into the wage equation. This strategy is unsuccessful, which confirms the previous results that, if at all, only a few traits contribute to the explanation of individual earnings differentials and that using an aggregate measure swallows the channels through which non-cognitive skills affect wages. Column 4 shows the estimation results of a wage equation without controlling for education. This also leads to significant effects for Conscientiousness, Openness, and Neuroticism but at the expense 
of a loss in explanatory power of more than two thirds. In this case, Extraversion is no longer significant. One possible explanation for this is that the intraindividual traits Conscientiousness, Openness, and Neuroticism affect wages only indirectly through a higher education attainment and are, therefore, only significant when not controlling for education.

Finally, in order to alleviate a potential bias due to endogeneity of the Big Five we also present estimates for the wage equation based on the 2007 cross-section using the Big Five regressors of 2005 as predetermined variables (column 5). The estimation results are very similar. Extraversion and Agreeableness are still the only personality traits having a significant effect on wages: The size of the effect stays almost the same and the significance level is slightly lower in both cases. These results support our implicit assumption that the self-assessments of the traits are not suffering from reverse causation and are not affected by the current wage situation. Most of the effects of the Big Five on wages are indirect ones affecting wages by higher educational attainment. This robustness exercise points out that the Big Five personalty traits can be treated as time constant individual effects. Our estimation results for the other specifications of the wage equation also do not change when using the cross-section of 2007 (not displayed here).

A potential endogeneity problem arises from the fact that the self-assessments of personality traits are context related and may result from status in the labor force. In this case, we would have to find appropriate instruments for the participation equation. In order to address this potential endogeneity problem, we run a regression of the Big Five measured in 2005 on the participation status of the previous years and their interaction terms. Table A5 displays the regression results for the Big Five Traits where we also include age in order to control for possible changes over the life cycle. The explanatory variables in this setting are dummy variables that take on the value "1" if the women was participating in the labor force at the time of the interview in the corresponding year. Note that the sample size of these regressions are smaller due to missing values in the panel. The setting of the regression allows us to test whether or not a change from participating to not participating in the labor market has a different effect on a women's personality traits than a change from not participating to participating. If this where the case, we would have evidence for a non negligible endogeneity issue. However, the corresponding tests show that these two effects are not significantly different $(p>0.5)$, which again 
supports our assumption of exogenous personality traits in the labor force participation decision. Moreover, it is worth noting that some personality traits show some life-cycle pattern. In particular, Conscientiousness and Extraversion increase over the lifetime but with diminishing rates. However, since we only have one cross section, we cannot identify, whether this is an age or an cohort effect.

Table 5: Heckit Estimates of the Wage Equation

\begin{tabular}{l|rr|rr}
\hline \hline & \multicolumn{2}{|c|}{ Wage equation } & \multicolumn{2}{c}{ Selection equation } \\
\hline EAST & -0.2310 & $(0.00)$ & 0.1217 & $(0.04)$ \\
AGE & 0.0175 & $(0.08)$ & 0.0323 & $(0.00)$ \\
$A G E^{2} * 0.01$ & -0.0148 & $(0.23)$ & & \\
GERMAN & 0.1107 & $(0.00)$ & 0.3473 & $(0.00)$ \\
MID_VOC & 0.0410 & $(0.15)$ & 0.0872 & $(0.23)$ \\
HIGH_VOC & 0.1404 & $(0.00)$ & 0.3675 & $(0.00)$ \\
HIGH_EDU & 0.4257 & $(0.00)$ & 0.5736 & $(0.00)$ \\
CONST & 1.5690 & $(0.00)$ & -1.3393 & $(0.00)$ \\
\hline MARR & & & -0.3868 & $(0.00)$ \\
NOT_SATISFIED & & & -0.1375 & $(0.07)$ \\
PAR_CLOSE & & & 0.1297 & $(0.01)$ \\
logHH_INC & & & -0.0300 & $(0.04)$ \\
ONE_CHILD & & & -0.5554 & $(0.00)$ \\
TWO_CHILD & & & -0.7477 & $(0.00)$ \\
THREE_CHILD & & & -1.1521 & $(0.00)$ \\
\hline EXT (2005) & 0.0212 & $(0.02)$ & 0.0971 & $(0.00)$ \\
AGREE (2005) & -0.0175 & $(0.05)$ & -0.0638 & $(0.02)$ \\
CONSC (2005) & -0.0230 & $(0.04)$ & 0.2009 & $(0.00)$ \\
NEU (2005) & 0.0010 & $(0.90)$ & -0.0677 & $(0.01)$ \\
OPEN (2005) & -0.0024 & $(0.79)$ & -0.0480 & $(0.08)$ \\
\hline$\lambda$ & -0.1366 & $(0.00)$ & & \\
Nobs. & 2,127 & & 3,390 & \\
\hline \hline
\end{tabular}

Dependent variable: log hourly wages, p-values in parenthesis.

Standardized values of the Big Five Traits.

The results of the wage equation corrected for sample selectivity are given in Table 5 (further specifications of the wage equation are given in Tabel 6 of Appendix A). The variables MARR, NOT_SATISFIED, PAR_CLOSE, logHH_INC, and the number of children are used as instruments entering the selection equation but are excluded from the wage equation. Except for the effect of Conscientiousness, which is now significantly negative, there are no substantial differences to report compared to the conventional OLS results on the sample of working women. The negative 
sign on Conscientiousness is somewhat surprising because we would expect that this personality trait is valued by employers. Since the existence of sample selectivity, cannot be rejected at conventional significance levels, we use the estimates of the Heckit to compute the imputed wages for the structural participation equation. The estimates used for the imputation procedure including the selection equation are displayed in Table 5 (same model specification as in column 2 of Table 6). Figure B2 in Appendix B illustrates the distribution of the imputed wages for participating and non-participating women.

The results of the structural participation equation using imputed hourly wages for all women are given in Table 6 where the average marginal effects are displayed. In the following we exclude household income from our model since it turned out to be insignificant $(p>0.9)$ in all specifications. This finding is in line with many previous labor supply studies for Germany and other countries and provides support for our choice of a parallel preference function. The results in column 2 show that all personality traits except Agreeableness significantly influence the participation decision. Women with high self-regulatory skills, as captured by the overall factor Conscientiousness, are more likely to participate in the labor force. This trait has the strongest impact on the participation probability. The effect of Extraversion is also positive, but the corresponding coefficient is not even half the size of that for Conscientiousness. Openness to Experience and Neuroticism have a negative impact on the probability of participating in the labor market. The positive effect of Conscientiousness and the negative effect of Neuroticism are in line with our expectations as outlined in the discussion of the Big Five and labor force participation in Section 2.

The statistically insignificant coefficient on Agreeableness can be explained by the strong impact of this trait on wages. If we exclude wage from the participation equation (column 4), Agreeableness turns out to be negative and significant, at least at the $10 \%$-level. Given wages, more agreeable women may face a larger conflict in the choice between work and family. Unconditionally, they work less due to lower wages. Contrary to the findings for the wage equation, the Big Five-Index is significant in the participation equation (column 3). The loss of explanatory power in terms of the McFadden's Pseudo $R^{2}$ is comparatively small which implies that the use of unidimensional measures of personality traits may be a reasonable research strategy in this context. Since four out of five personality traits have an affect, the aggregate measure has explanatory power in the direction we expected: The higher 
the non-cognitive skills as measured by the index, the higher is the probability that a women will participate in the labor market. In order to illustrate the effect of the personality traits, Table 7 displays the change in the predicted participation probability given certain changes in the different traits. If we take Conscientiousness as the most important of the five traits, the expected difference in the participation probability between two women one with maximum and one with minimum score equals 42 percentage points (keeping all other explanatory variables constant at their mean). If we only look at change of half a standard deviation around the mean, this difference is only 5 percentage points. However, the results of Table 7 illustrate that the effects of non-cognitive skills are not negligible in the labor force participation decision of women.

Column 1 gives the estimates of a conventional structural participation equation excluding measures of personality traits. If we compare column 1 and column 2, we find that, similar to the findings for the wage equation, significant coefficients remain significant and do not change sign. Most interestingly, the size of the coefficient on education drops dramatically and even becomes insignificant. This means that labor supply and labor force studies ignoring personality traits are likely to exaggerate the effect of education on labor supply. In these studies education simply proxies the omitted personality traits to a large extend.

The wage effect is not significant in any of the model specifications given in Table 6. This is in line with the finding that wage effects for the female labor supply have decreased or even vanished over the last decades (Heim (2007)). A comparison of the full model in column 2 with the estimates given in column 4 in which the wage variable is excluded shows that the effects of the Big Five on the participation probability do not change. The coefficient estimates are nearly stable - only Agreeableness becomes more significant - supporting our hypothesis that much of the effects of the Big Five on labor force participation is preference driven rather than wage driven.

Even though the regression of the Big Five on previous labor force participation did not indicate that personal traits are affected by the present employment status, we perform another robustness check by estimating the participation equation based on the 2007 cross-section using the Big Five regressors from 2005 as pre-determined variables. We do not find substantial changes in the results. In fact, the coefficients for the Big Five are now larger and estimated with greater precision: now even the 
effect of Agreeableness is significantly negative.

Table 6: Estimates of the Structural Participation Equation

\begin{tabular}{|c|c|c|c|c|c|}
\hline & $\begin{array}{l}\text { without } \\
\text { Big } 5\end{array}$ & $\begin{array}{l}\text { with } \\
\text { Big } 5\end{array}$ & $\begin{array}{l}\text { Big 5-Index } \\
005\end{array}$ & $\begin{array}{l}\text { without } \\
\text { log wage }\end{array}$ & $\begin{array}{c}\text { Cross-section } \\
2007\end{array}$ \\
\hline EAST & $\begin{array}{c}0.1173 \\
(0.00)\end{array}$ & $\begin{array}{c}0.1499 \\
(0.00)\end{array}$ & $\begin{array}{c}0.1354 \\
(0.00)\end{array}$ & $\begin{array}{c}0.1127 \\
(0.00)\end{array}$ & $\begin{array}{c}-0.0530 \\
(0.14)\end{array}$ \\
\hline AGE & $\begin{array}{c}-0.0036 \\
(0.72)\end{array}$ & $\begin{array}{c}-0.0140 \\
(0.15)\end{array}$ & $\begin{array}{c}-0.0066 \\
(0.50)\end{array}$ & $\begin{array}{c}-0.0104 \\
(0.27)\end{array}$ & $\begin{array}{c}-0.0044 \\
(0.69)\end{array}$ \\
\hline$A G E^{2} * 0.01$ & $\begin{array}{c}0.0020 \\
(0.87)\end{array}$ & $\begin{array}{c}0.0130 \\
(0.26)\end{array}$ & $\begin{array}{c}0.0050 \\
(0.67)\end{array}$ & $\begin{array}{c}0.0102 \\
(0.38)\end{array}$ & $\begin{array}{c}0.0020 \\
(0.88)\end{array}$ \\
\hline GERMAN & $\begin{array}{c}0.1111 \\
(0.00)\end{array}$ & $\begin{array}{c}0.0870 \\
(0.00)\end{array}$ & $\begin{array}{c}0.0992 \\
(0.00)\end{array}$ & $\begin{array}{c}0.1055 \\
(0.00)\end{array}$ & $\begin{array}{c}0.1558 \\
(0.00)\end{array}$ \\
\hline EDUCATION & $\begin{array}{c}0.0548 \\
(0.00)\end{array}$ & $\begin{array}{c}0.0268 \\
(0.18)\end{array}$ & $\begin{array}{c}0.0382 \\
(0.03)\end{array}$ & $\begin{array}{c}0.0555 \\
(0.00)\end{array}$ & $\begin{array}{c}0.0801 \\
(0.00)\end{array}$ \\
\hline imp. logHOUR_WAGE & $\begin{array}{c}-0.0013 \\
(0.99)\end{array}$ & $\begin{array}{c}0.2022 \\
(0.12)\end{array}$ & $\begin{array}{c}0.0871 \\
(0.44)\end{array}$ & & $\begin{array}{c}-0.0282 \\
(0.84)\end{array}$ \\
\hline MARR & $\begin{array}{c}-0.1244 \\
(0.00)\end{array}$ & $\begin{array}{c}-0.1246 \\
(0.00)\end{array}$ & $\begin{array}{c}-0.1240 \\
(0.00)\end{array}$ & $\begin{array}{c}-0.1248 \\
(0.00)\end{array}$ & $\begin{array}{c}-0.0976 \\
(0.00)\end{array}$ \\
\hline ONE_CHILD & $\begin{array}{c}-0.0718 \\
(0.02)\end{array}$ & $\begin{array}{c}-0.0740 \\
(0.01)\end{array}$ & $\begin{array}{c}-0.0757 \\
(0.01)\end{array}$ & $\begin{array}{c}-0.0751 \\
(0.01)\end{array}$ & $\begin{array}{c}-0.0624 \\
(0.05)\end{array}$ \\
\hline TWO_CHILD & $\begin{array}{c}-0.1309 \\
(0.00)\end{array}$ & $\begin{array}{c}-0.1282 \\
(0.00)\end{array}$ & $\begin{array}{c}-0.1325 \\
(0.00)\end{array}$ & $\begin{array}{c}-0.1287 \\
(0.00)\end{array}$ & $\begin{array}{c}-0.1200 \\
(0.00)\end{array}$ \\
\hline THREE_CHILD & $\begin{array}{c}-0.2739 \\
(0.00)\end{array}$ & $\begin{array}{c}-0.2684 \\
(0.00)\end{array}$ & $\begin{array}{c}-0.2767 \\
(0.00)\end{array}$ & $\begin{array}{c}-0.2681 \\
(0.00)\end{array}$ & $\begin{array}{c}-0.2906 \\
(0.00)\end{array}$ \\
\hline EXT (2005) & & $\begin{array}{c}0.0278 \\
(0.00)\end{array}$ & & $\begin{array}{c}0.0318 \\
(0.00)\end{array}$ & $\begin{array}{c}0.0394 \\
(0.00)\end{array}$ \\
\hline AGREE (2005) & & $\begin{array}{c}-0.0112 \\
(0.17)\end{array}$ & & $\begin{array}{c}-0.0145 \\
(0.07)\end{array}$ & $\begin{array}{c}-0.0352 \\
(0.00)\end{array}$ \\
\hline CONSC (2005) & & $\begin{array}{c}0.0611 \\
(0.00)\end{array}$ & & $\begin{array}{l}0.0557 \\
(0.00)\end{array}$ & $\begin{array}{c}0.0625 \\
(0.00)\end{array}$ \\
\hline NEU (2005) & & $\begin{array}{c}-0.0196 \\
(0.01)\end{array}$ & & $\begin{array}{c}-0.0194 \\
(0.01)\end{array}$ & $\begin{array}{c}-0.0312 \\
(0.00)\end{array}$ \\
\hline OPEN (2005) & & $\begin{array}{c}-0.0239 \\
(0.00)\end{array}$ & & $\begin{array}{c}-0.0241 \\
(0.00)\end{array}$ & $\begin{array}{c}-0.0270 \\
(0.01)\end{array}$ \\
\hline $\begin{array}{l}\text { Big Five Index } \\
(2005)\end{array}$ & & & $\begin{array}{l}0.0409 \\
(0.00)\end{array}$ & & \\
\hline Nobs. & 3,390 & 3,390 & 3,390 & 3,390 & 2,616 \\
\hline McFadden's $R^{2}$ & 0.1094 & 0.1314 & 0.1171 & 0.1308 & 0.1367 \\
\hline Correctly classified & $75.63 \%$ & $76.43 \%$ & $75.96 \%$ & $76.34 \%$ & $73.74 \%$ \\
\hline $\log$ Lik & $-1,689$ & $-1,648$ & $-1,675$ & $-1,649$ & $-1,359$ \\
\hline
\end{tabular}

Average partial effects of the ML logit estimates, p-values in parenthesis. Imputed wages by Heckit estimates given in column 2 of Table 5. Standardized values of the Big Five Traits. 
Table 7: Effects on participation probability

\begin{tabular}{l|rr}
\hline \hline & min to max & $\begin{array}{r}+\backslash-\frac{1}{2} \text { std.dev. } \\
\text { around mean }\end{array}$ \\
\hline EXT & 0.1629 & 0.0282 \\
AGREE & -0.0555 & $-0.010{ }^{*}$ \\
CONSC & 0.4160 & 0.0537 \\
NEU & -0.0983 & -0.0195 \\
OPEN & -0.1145 & -0.0233 \\
\hline Big 5 Index & 0.2701 & 0.0392 \\
\hline \hline
\end{tabular}

*insignificant effect. Changes of the participation probability due to changes in the personality traits. Changes in percentage points, holding all other variables constant at their mean.

For the specifications estimated above we have implicitly assumed that the marginal rate of substitution between consumption and leisure changes over the life-cycle but the effects of the other socio-economic factors (e.g. children, education) and the effects of the personality traits remain constant. Our results presented Table 6, however, indicate no significant age pattern for the preferences for all specifications.

The assumption of age-invariant effects of these factors on labor force participation is relaxed in the following by allowing for heterogeneity in the preference parameters by age group. We define three age groups: the first one includes women aged from 25 to 34 at the beginning of their work-life and possibly with young children, the second group consists of women between age 35 and 44, and finally the oldest group consists of woman at aged from 45 to 54 . The labor force participation rate for these three age groups are $81 \%, 75 \%$, and $72 \%$, respectively. Using dummy variables for these three groups we interact all explanatory variables, where the youngest group is the reference group. The effect of having a child on labor force participation may well decrease over the life-cycle as the child gets older and eventually leaves the parents' house. Similar arguments can be found for other socio-economic factors. The estimates from the structural participation equation allowing for different effects for different age groups are presented in Table 8. Almost all interaction terms of the Big Five are insignificant. When testing for jointly significance of the interaction 
terms of the personality traits, we cannot reject the null $(p=0.13)$. Thus, we can conclude that we do not find any significant evidence that the impact of personality traits on the marginal rate of substitution between leisure and consumption changes over the life-cycle. Not too surprising, is the age heterogeneity for the coefficients on other socio-economic factors, in particular, the variables for the number of children.

Based on the estimated wage equation and the participation equation, we can now identify the direct (or net) effect of the Big Five on female labor force participation as well as the indirect effect of the personality traits through wages. Figure B3 illustrates the odds ratios for the five traits, where the solid line represents the net effect based on the participation equation including the imputed log hourly wage (Column 2 in Table 6). The dashed line represents the combination of the net effect and the effect through wages using the estimation results of the participation equation excluding the log hourly wage (Column 4 in Table 6). We see that difference between the two effects is obvious for the three traits Extraversion, Agreeableness, and Conscientiousness, while the effect through wage is negligible for Neuroticism and Openness where we find almost no difference. In the case of Extraversion, the additional effect through wages is positive such that the odds ratio becomes higher. For Agreeableness and Conscientiousness, we observe a diminishing effect through wages on the participation probability, which reflects the negative sign of these two traits in the wage equation. 
Table 8: Estimates of the Structural Participation Equation with time varying preferences

\begin{tabular}{|c|c|c|c|c|}
\hline & Coefficient & p-value & Coefficient & p-value \\
\hline EAST & -0.0932 & $(0.30)$ & -0.0289 & $(0.72)$ \\
\hline EAST * Age $35-44$ & 0.2243 & $(0.00)$ & 0.2018 & $(0.00)$ \\
\hline EAST $*$ Age $45-54$ & 0.2107 & $(0.00)$ & 0.1535 & $(0.00)$ \\
\hline GERMAN & 0.2952 & $(0.00)$ & 0.2770 & $(0.00)$ \\
\hline GERMAN * Age $35-44$ & -0.2000 & $(0.01)$ & -0.1920 & $(0.01)$ \\
\hline GERMAN * Age $45-54$ & -0.2464 & $(0.00)$ & -0.2151 & $(0.00)$ \\
\hline EDUCATION & 0.1437 & $(0.00)$ & 0.1099 & $(0.00)$ \\
\hline EDUCATION * Age $35-44$ & -0.1398 & $(0.00)$ & -0.1102 & $(0.01)$ \\
\hline EDUCATION * Age $45-54$ & -0.1553 & $(0.00)$ & -0.0934 & $(0.04)$ \\
\hline imp. logHOUR_WAGE & -0.6506 & $(0.02)$ & -0.4030 & $(0.12)$ \\
\hline imp. logHOUR_WAGE $*$ Age $35-44$ & 0.9101 & $(0.01)$ & 0.6952 & $(0.02)$ \\
\hline imp. logHOUR_WAGE $*$ Age $45-54$ & 1.1711 & $(0.00)$ & 0.7263 & $(0.02)$ \\
\hline MARR & -0.0660 & $(0.17)$ & -0.0696 & $(0.15)$ \\
\hline MARR * Age 35-44 & -0.0975 & $(0.17)$ & -0.0973 & $(0.17)$ \\
\hline MARR * Age 45-54 & -0.0509 & $(0.47)$ & -0.0465 & $(0.51)$ \\
\hline ONE_CHILD & -0.0904 & $(0.19)$ & -0.0954 & $(0.17)$ \\
\hline ONE_CHILD $*$ Age $35-44$ & -0.0640 & $(0.46)$ & -0.0610 & $(0.49)$ \\
\hline ONE_CHILD * Age $45-54$ & 0.0824 & $(0.16)$ & 0.0894 & $(0.12)$ \\
\hline TWO_CHILD & -0.2360 & $(0.00)$ & -0.2375 & $(0.00)$ \\
\hline TWO_CHILD * Age 35-44 & 0.0585 & $(0.40)$ & 0.0561 & $(0.40)$ \\
\hline TWO_CHILD * Age 45-54 & 0.1760 & $(0.00)$ & 0.1808 & $(0.00)$ \\
\hline THREE_CHILD & -0.3555 & $(0.00)$ & -0.3623 & $(0.00)$ \\
\hline THREE_CHILD * Age 35-44 & 0.0009 & $(0.99)$ & -0.0005 & $(0.99)$ \\
\hline THREE_CHILD * Age 45-54 & 0.1386 & $(0.00)$ & 0.1466 & $(0.00)$ \\
\hline Age $35-44$ & -0.5583 & $(0.04)$ & -0.5562 & $(0.02)$ \\
\hline Age $45-54$ & -0.5841 & $(0.04)$ & -0.5836 & $(0.02)$ \\
\hline EXT & 0.0529 & $(0.00)$ & 0.0295 & $(0.00)$ \\
\hline EXT $*$ Age $35-44$ & -0.0374 & $(0.10)$ & & \\
\hline EXT * Age $45-54$ & -0.0248 & $(0.27)$ & & \\
\hline AGREE & -0.0204 & $(0.29)$ & -0.0124 & $(0.13)$ \\
\hline AGREE * Age $35-44$ & -0.0038 & $(0.87)$ & & \\
\hline AGREE * Age 45-54 & 0.0229 & $(0.32)$ & & \\
\hline CONSC & 0.0275 & $(0.17)$ & 0.0593 & $(0.00)$ \\
\hline CONSC * Age 35-44 & 0.0293 & $(0.24)$ & & \\
\hline CONSC * Age $45-54$ & 0.0497 & $(0.04)$ & & \\
\hline $\mathrm{NEU}$ & 0.0056 & $(0.76)$ & -0.0202 & $(0.01)$ \\
\hline NEU * Age $35-44$ & -0.0213 & $(0.33)$ & & \\
\hline NEU * Age $45-54$ & -0.0397 & $(0.07)$ & & \\
\hline OPEN & -0.0396 & $(0.04)$ & -0.0242 & $(0.00)$ \\
\hline OPEN * Age 35-44 & 0.0264 & $(0.25)$ & & \\
\hline OPEN $*$ Age $45-54$ & 0.0149 & $(0.51)$ & & \\
\hline McFadden's $R^{2}$ & 0.1473 & & 0.1432 & \\
\hline Correctly classified & $76.78 \%$ & & $76.76 \%$ & \\
\hline $\log \mathrm{Lik}$ & $-1,617$ & & $-1,625$ & \\
\hline
\end{tabular}

Average partial effects of the ML logit estimation, p-values in parenthesis. Imputed wages by Heckit estimates given in column 2 of Table 5 . Standardized values of the Big Five Traits. 


\section{Conclusion}

The goal of this paper is to assess the role of non-cognitive skills, defined here as the Big Five personality traits, for female labor market participation. In particular, we are focussing on the channels through which these personalty traits affect labor force participation. This is done by estimating a structural labor force participation equation which allows us to interpret the effects of personality traits on labor force in terms of individual heterogeneity in preferences.

Our findings are very much in line with many empirical studies claiming that noncognitive skills play a non-negligible role in explaining individual behavior in the labor market. In particular, the results of our study exemplify that ignoring personality traits exaggerates the effect of education on labor force participation. Educational attainment and (female) labor force participation are simply two different outcome dimensions driven by personality traits.

We find a strong impact of the interindividual skills Extraversion and Agreeableness, whereby the former has a positive and the latter a negative effect on wages. Since the wage elasticity of labor supply is rather small and not significantly different from zero, the impact of personality traits on labor force participation is largely a direct one. Conscientiousness is the Big 5 trait with the strongest positive effect. Why this particular trait plays such a prominent role requires further investigation, which is beyond the scope of the current study. Extraversion shows a positive, albeit smaller, effect, as well. Neuroticism and Openness both have a negative effect of about the same size on female labor market participation probability. The use of single index for to capture the effects of personality traits on female labor force participation is possible but problematic since the effects differ in size and sign.

Our study expands our understanding of preference heterogeneity and, consequently, of the heterogeneity of individual decisions. By endogenizing preference parameters and relating them to personality traits, the approach taken is admittedly a rather simple one. It yields some evidence that the Big 5 concept of personal psychology is strongly related to preference parameters as suggested by Borghans, Duckworth, Heckman, and Ter Weel (2008). Various robustness checks show that self-assessed personality traits serve well as explanatory variables for labor force participation. Surprisingly, the effects of personality traits on preferences are much more stable 
over the life-cycle compared to other socio-economic factors. We find strong evidence that preferences change over the life-cycle. However, we do not observe time varying effects for the Big Five personality traits.

In our study the Big 5 traits turn out to be rather stable over the life-cycle and orthogonal to the individuals labor force history. Future research should take the formation of personality traits and preference formation building on a model of preference formation into account. Another path of future research should be concerned with identification issues. Personality traits not only effect the preferences determining the marginal rate of substitution between leisure and consumption but also preferences towards risk and intertemporal substitution. 


\section{References}

Ainslie, G., And J. Monterosso (2004): "Behavior: A Marketplace in the Brain?," Science, 306, $421-423$.

Barrick, M., And M. Mount (1991): "The Big Five Personality Dimensions and Job Performance: A Meta-Analysis," Personnel Psychology, 44, 1-26.

Bernal, R., And M. Keane (2006): "Child Care Choices and Childrens Cognitive Achievement: The Case of Single Mothers," Discussion paper, Northwestern University, Working Paper.

Borghans, L., A. L. Duckworth, J. J. Heckman, and B. Ter Weel (2008): "The Economics and Psychology of Personality Traits," Jornal of Human Resources, 43, 817 -860 .

Bowles, S., H. Gintis, And M. Osborne (2001a): "The Determinans of Earnings: A Behavioral Approach," Journal of Economic Literature, 39, 1137 - 1176.

Bowles, S., H. Gintis, And M. Osborne (2001b): "Incentive-Enhancing Preferences: Personality, Behavior, and Earnings," American Economic Review, 91, 155 - 158.

Carneiro, P., C. Crawford, and A. Goodman (2007): "Which Skills Matter?," in Practice Makes Perfect: The Importance of Practical Learning, ed. by D. Kehoe. Social market Foundation.

Carneiro, P., and J. J. Heckman (2002): "The Evidence on Credit Constraints in Post-Secondary Schooling," The Economic Journal, 112, 705-734.

Caspi, A., And B. W. Roberts (2001): "Personality Development across the Life Course: The Argument for Change and Continuity," Psychological Inquiry, 12, 49-66.

Conley, J. J. (1985): "Longitudinal Stability of Personality Traits: A MultitraitMultimethod-Multioccasion Analysis," Journal of Personality and Social Psychology, 49.

Costa, P. T., J. H. Herbst, R. R. McCrae, And I. C. Siegler (2000): "Personality at Midlife: Stability, Intrinsic Maturation, and Response to Life Events," Assessment, $7,365-378$.

Costa, P. T., And R. R. McCrae (1992): NEO RI-R Professional Manual. Psychological Assessments Resources, Odessa, Florida.

(1995): "Domains and Facets: Hierarchical Personality Assessment Using the Revised NEO Personality Inventory," Journal of Personality Assessment, 64, 21-50.

(1999): "A Five-Factor Theory of Personality," in Handbook of Personality: Theory and Research, ed. by L. A. Pervin, and O. P. John, pp. 139 - 153. Guilford, New York.

(2006): "Age Changes in Personality and Their Origins: Comment on Roberts, Walton, and Viechtbauer (2006)," Psychological Bulletin, 132, 26-28. 
Dehne, M., AND J. Schupp (2007): "Persönlichkeitsmerkmale im Sozio-oekonomischen Panel (SOEP) - Konzept, Umsetzung und empirische Eigenschaften," Discussion paper, German Institute for Economic Research, DIW Research Note 26.

Duckworth, A. L., And M. E. Seligman (2005): "Self-Discipline Outdoes IQ in Predicting Academic Performance of Adolescents," Psychological Science, 16, 939-944.

Erdheim, J., M. WANG, AND M. Zickar (2006): "Linking the Big Five personality constructs to organizational commitment," Personality and Individual Differences, 41, 959-970.

Fahr, R., And S. Kusche (2008): "Individual Determinants of Work Attendance: Evidence on the Role of Personality," University of Cologne, unpublished working paper.

Flossmann, A., R. Piatek, And L. Wichert (2007): "Going Beyond Returns to Education: The Role of Noncognitive Skills on Wages in Germany," University of Konstanz, DFG Research Group Heterogeneous Labor, unpublished working paper.

Gerlitz, J.-Y., And J. Schupp (2005): "Zur Erhebung der Big-Five-basierten Persoenlichkeitsmerkmale im SOEP," Discussion paper, German Institute for Economic Research, DIW Research Note 4.

Green, D. A., And W. C. Riddell (2002): "Literacy Skills, Non-Cognitive Skills and Earnings: An Investigation of the Interaction of Cognitive and Noncognitive Attributes in Earnings Generation," Labour Economics, 10, 165 - 184.

Green, L., And J. Myerson (2004): "A Discounting Framework for Choice with Delayed and Probabilistic Rewards," Pschological Bulletin, 130, 769 - 792.

Gregg, P., E. Washbrook, C. Propper, And S. Burgess (2005): "The Effects of a Mother's Return to Work Decision on Child Development in the UK," Economic Journal, 115, $48-80$.

Gustavsson, J. P., R. M. Weinryb, S. Gransson, N. L. Pedersen, and M. Asberg (1997): "Stability and predictive ability of personality traits across 9 years," Personality and Individual Differences, 22.

Harvey, E. (1999): "Short-Term and Long-Term Effects of Early Parental Employment on Children of the National Longitudinal Survey of Youth," Development Psychology, $35,445-459$.

Heckman, J. J., J. Stixrud, and S. Urzua (2006): "The Effects of Cognitive and Noncognitive Abilities on Labor Market Outcomes and Social Behavior," Journal of Labor Economics, 24, $411-482$.

Heim, B. T. (2007): "The Incredible Shrinking Elasticities Married Female Labor Supply, 1978 - 2002," Journal of Human Resources, 42, 881-918.

Heineck, G., And S. Anger (2008): "The Returns to Cognitive Abilities and Personality Traits in Germany," Discussion paper, German Institute for Economic Research. 
Hill, L., J. Waldvogel, J. Brooks-Gunn, And W. Han (2005): "Maternal Employment and Child Development: A Fresh Look Using Never Methods," Development Psychology, 41, 833 - 850 .

JACOB, B. A. (2002): "Where the boys aren't: Non-cognitive skills, returns to school and the gender gap in higher education," Economics of Education Review, 21, 589 - 598.

John, O., And S. SRivastava (1999): "Big Five Trait Taxonomy. History, Measurement, and Theoretical Perspectives," in Handbook of Personality. Theory and Research, ed. by L. Pervin, and O. John, pp. 102-139. Guilford, New York.

Koebel, B., F. Laisney, W. Pohlmeier, and M. Staat (2008): "Estimation of Labour Supply Functions Using Panel Data: A Survey, ," in The Economics of Panel Data: Theory and Applications, ed. by L. Matyas, and P. Sevestre, chap. 23, pp. 763796. Springer, Heidelberg, 3rd edn.

König, H., F. Laisney, M. Lechner, and W. Pohlmeier (1995): "Tax Illusion and Labour Supply of Married Woman: Evidence from German Data," Kyklos, 48, 347-368.

Laisney, F., M. Lechner, A. van Soest, and G. Wagenhals (1993): "A Life Cycle Labour Supply Model with Taxes Estimated on German Panel Data : The Case of Parallel Preferences," Economic and Social Review, 24, 335368.

Merz, M. (2005): "Womens's Hours of Market Work in Germany," in Labour Supply and Incentive to Work in Europe, ed. by R. Gómez-Salvador, A. Lamo, B. Pertrongolo, M. Ward, and E. Wasmer, pp. 153 - 190. Edward Elgar Publishing, Northampton, MA.

Mueller, G., And E. Plug (2006): "Estimating the Effect of Personality on MaleFemale Earnings," Industrial and Labor Relations Review, 60, 3 - 22.

Nyhus, E., And E. Pons (2005): "The Effects of Personality on Earnings," Journal of Economic Psychology, 26, 363384.

Piatek, R., And P. Pinger (2009): "Maintaining (locus of) control?," Discussion paper, presented at the Conference of Leibniz Research Network "Non-Cognitive Skills: Acquisition and Economic Consequences", Hegne Monastery, March 2009.

Rachlin, H. (2006): "Notes on Discounting," Journal of Experimental Analysis of Behavior, 85, $425-435$.

Ruhm, C. (2004): "Parental Employment and Child Cognitive Development," Journal of Human Ressources, 39, 155 - 192.

Seibert, S., And M. Kraimer (1995): "The Five-Factor Model of Personality and Career Success," Journal of Vocational Behavior, 58, 1-21.

Srivastava, S., O. P. John, S. D. Gosling, and J. Potter (2003): "Development of Personality in Early and Middle Adulthood: Set Like Plaster or Persistent Change?," Journal of Personality and Social Psychology, 84, 1041-1053.

TAvares, L. (2008): "Who delays childbearing? The relatioship between fertility, education and personality traits," Discussion paper, Institute for Social and Economic Research, University of Essex. 
VEARING, A., AND A. MAK (2007): "Big five personality and effort-reward imbalance factors in employees' depressiv symptoms," Personality and Individual Differences, 43.

Zetterberg, J. (2005): "Swedish evidence on the impact of cognitive and non-cognitive ability on earnings an extended pre-market factor approach," IFAU Institute for Labour Market Pliccy Evaluation, Working Paper 205:16. 


\section{A Data}

Table A1: Definition of Variables

\begin{tabular}{|c|c|}
\hline Variable & Definition \\
\hline AGE & Age in years \\
\hline logHOUR_WAGE & $\ln$ (Hourly wage (Euro) based on the agreed upon work time per week) \\
\hline logHH_INC & $\ln$ (net household income minus net wage of the women) \\
\hline GERMAN & Dummy, 1 if German \\
\hline EAST & Dummy, 1 if living in East Germany \\
\hline STATE & Indicator for the different Federal States \\
\hline MARR & Dummy, 1 if women is married \\
\hline ONE_CHILD & Dummy, 1 if women has one child \\
\hline TWO_CHILD & Dummy, 1 if women has two children \\
\hline THREE_CHILD & Dummy, 1 if women has three or more children \\
\hline PARTIC & Dummy, 1 if women participates in the labor market \\
\hline FULLTIME & Dummy, 1 if full-time employed \\
\hline PARTTIME & Dummy, 1 if part-time employed \\
\hline LOW_VOC & Dummy, 1 if no degree or less or equal than 10 years of schooling (reference group) \\
\hline MID_VOC & Dummy, 1 if high school degree (12 or 13 years of schooling) or vocational training \\
\hline HIGH_VOC & Dummy, 1 if high school degree and vocational training \\
\hline HIGH_EDU & Dummy, 1 if highest degree is university degree \\
\hline EDUCATION & 0 if $\mathrm{LOW} \_\mathrm{VOC}=1 ; 1$ if MID_VOC $=1 ; 2$ if $\mathrm{HIGH}_{-} \mathrm{VOC}=1 ; 3$ if HIGH_EDU $=1$ \\
\hline PAR_CLOSE & Dummy, 1 if parents live in the same household or in the same city \\
\hline NOT_SATISFIED & Dummy, 1 if not satisfied with the child care situation \\
\hline EXT & Score for Extraversion (from 3 to 21 (very pronounced)) \\
\hline AGREE & Score for Agreeableness (from 3 to 21 (very pronounced)) \\
\hline CONSC & Score for Consciousness (from 3 to 21 (very pronounced)) \\
\hline NEU & Score for Neuroticism (from 3 to 21 (very pronounced)) \\
\hline EMOSTAB & $=-(N E U-24)$, measure for the inverse of Neuroticism (Emotional Stability) \\
\hline OPEN & Score for Openness to Experience (from 3 to 21 (very pronounced)) \\
\hline BigFiveIndex & $\begin{array}{l}\text { Score of the Big Five-Index }(C O N S C+A G R E E+O P E N+E X T+E M O S T A B) \\
\text { (from } 15 \text { (low noncognitive skills) to } 105 \text { (high noncognitive skills)) }\end{array}$ \\
\hline
\end{tabular}

SOEP, Wave 2005 
Table A2: Summary Statistics

\begin{tabular}{|c|c|c|c|c|}
\hline & Full Sample & Participating & Not Participating & $\begin{array}{l}\text { t-test for mean diff. } \\
\text { p-values }\end{array}$ \\
\hline \multirow[t]{2}{*}{$\mathrm{AGE}$} & 41.04 & 40.68 & 42.12 & 0.00 \\
\hline & $(7.93)$ & $(8.00)$ & $(7.61)$ & \\
\hline \multirow[t]{2}{*}{ logHOUR_WAGE } & 2.16 & 2.16 & -- & \\
\hline & $(0.41)$ & $(0.41)$ & -- & \\
\hline \multirow[t]{2}{*}{ Imputed logHOUR_WAGE } & 2.23 & 2.24 & 2.21 & 0.00 \\
\hline & $(0.22)$ & $(0.23)$ & $(0.19)$ & \\
\hline \multirow[t]{2}{*}{$\log \mathrm{HH} \_\mathrm{INC}$} & 7.30 & 7.28 & 7.37 & 0.17 \\
\hline & $(1.59)$ & $(1.48)$ & $(1.89)$ & \\
\hline GERMAN & 0.91 & 0.94 & 0.83 & 0.00 \\
\hline EAST & 0.24 & 0.28 & 0.13 & 0.00 \\
\hline MARR & 0.82 & 0.79 & 0.93 & 0.00 \\
\hline ONE_CHILD & 0.26 & 0.28 & 0.18 & 0.00 \\
\hline TWO_CHILD & 0.40 & 0.39 & 0.43 & 0.08 \\
\hline THREE_CHILD & 0.18 & 0.14 & 0.32 & 0.00 \\
\hline PARTIC & 0.75 & 1 & 0 & \\
\hline FULLTIME & 0.33 & 0.44 & 0 & \\
\hline PARTTIME & 0.29 & 0.39 & 0 & \\
\hline LOW_VOC (reference) & 0.14 & 0.11 & 0.25 & 0.00 \\
\hline MID_VOC & 0.48 & 0.47 & 0.51 & 0.06 \\
\hline HIGH_VOC & 0.16 & 0.17 & 0.14 & 0.04 \\
\hline HIGH_EDU & 0.22 & 0.25 & 0.12 & 0.00 \\
\hline EDUCATION & 1.46 & 1.57 & 1.15 & 0.00 \\
\hline PAR_CLOSE & 0.30 & 0.31 & 0.27 & 0.04 \\
\hline NOT_SATISFIED & 0.10 & 0.11 & 0.09 & 0.25 \\
\hline \multirow[t]{2}{*}{ EXT } & 14.85 & 15.04 & 14.27 & 0.00 \\
\hline & $(3.37)$ & $(3.32)$ & $(3.44)$ & \\
\hline \multirow[t]{2}{*}{ AGREE } & 16.76 & 16.75 & 16.79 & 0.68 \\
\hline & $(2.77)$ & $(2.75)$ & $(2.85)$ & \\
\hline \multirow[t]{2}{*}{ CONSC } & 18.17 & 18.34 & 17.67 & 0.00 \\
\hline & $(2.46)$ & $(2.34)$ & $(2.75)$ & \\
\hline \multirow[t]{2}{*}{ NEU } & 12.51 & 12.37 & 12.92 & 0.00 \\
\hline & $(3.54)$ & $(3.48)$ & $(3.68)$ & \\
\hline \multirow[t]{2}{*}{ OPEN } & 13.65 & 13.69 & 13.50 & 0.17 \\
\hline & $(3.53)$ & $(3.52)$ & $(3.55)$ & \\
\hline \multirow[t]{2}{*}{ BigFiveIndex } & 74.91 & 75.45 & 73.31 & 0.00 \\
\hline & $(9.11)$ & $(8.91)$ & $(9.51)$ & \\
\hline Nobs. & 3,390 & 2,551 & 839 & \\
\hline
\end{tabular}

SOEP, Wave 2005, Number of obs. $=3,390$; Sample means, standard deviation in parenthesis (only for non-dummy variables) 
Table A3: Number of Children by employment status (percentage)

\begin{tabular}{l|cccc|c}
\hline \hline & No children & 1 child & 2 children & 3 or more children & Total \\
\hline Not participating & 1.77 & 4.46 & 10.59 & 7.94 & 24.76 \\
Full-time employed & 11.07 & 9.32 & 10.00 & 2.77 & 33.17 \\
Part-time employed & 2.30 & 7.82 & 14.28 & 5.16 & 29.57 \\
Marginally employed & 0.00 & 0.15 & 0.03 & 0.03 & 0.21 \\
Maternity protection & 0.00 & 0.86 & 1.09 & 0.53 & 2.48 \\
Parental leave & 0.00 & 2.01 & 3.04 & 1.15 & 6.20 \\
Registered unemployed & & & & & \\
and willing to work & 0.65 & 0.97 & 1.21 & 0.80 & 3.63 \\
\hline Total & 15.79 & 25.58 & 40.25 & 18.38 & 100.00 \\
\hline
\end{tabular}

SOEP, Wave 2005, Number of obs. $=3,390$

Table A4: Correlations between the Big Five Personality Traits

\begin{tabular}{l|ccccc}
\hline \hline & Extraversion & Agreeableness & Conscientiousness & Neuroticism & Openness \\
\hline Extraversion & 1.0000 & & & & \\
Agreeableness & 0.0793 & 1.0000 & & & \\
Conscientiousness & 0.2178 & 0.3003 & 1.0000 & 1.0000 & \\
Neuroticism & -0.1656 & -0.1229 & -0.0839 & -0.0564 & 1.0000 \\
Openness & 0.3865 & 0.1005 & 0.2002 & & \\
\hline \hline
\end{tabular}

SOEP, Wave 2005, Number of obs. $=3,390$

Table A5: Dependency of personality traits on previous labor market participation

\begin{tabular}{l|rrrrr}
\hline \hline & Conscientiousness & Openness & Extraversion & Agreeableness & Neuroticism \\
\hline Age & 0.1777 & 0.0861 & 0.1967 & -0.0939 & -0.1078 \\
& $(0.00)$ & $(0.32)$ & $(0.02)$ & $(0.16)$ & $(0.21)$ \\
AGE $^{2} * 01$ & -0.2030 & -0.1033 & -0.2588 & 0.1281 & 0.1217 \\
Partic04 & $(0.01)$ & $(0.33)$ & $(0.01)$ & $(0.12)$ & $(0.25)$ \\
& 0.3472 & 0.1086 & 0.9487 & 0.1665 & 0.0800 \\
Partic03 & $(0.13)$ & $(0.74)$ & $(0.30)$ & $(0.52)$ & $(0.81)$ \\
& 0.1844 & 0.0151 & 0.5747 & 0.0461 & -0.1931 \\
Partic02 & $(0.49)$ & $(0.97)$ & $(0.12)$ & $(0.88)$ & $(0.62)$ \\
& -0.1210 & 0.1295 & 0.0742 & -0.4999 & -0.4121 \\
Partic04*Partic03 & $(0.62)$ & $(0.71)$ & $(0.83)$ & $(0.07)$ & $(0.24)$ \\
& -0.1132 & -0.5133 & -1.0142 & -0.5386 & -0.3258 \\
Partic03*Partic02 & $(0.72)$ & $(0.26)$ & $(0.02)$ & $(0.13)$ & $(0.47)$ \\
& 0.4342 & 0.5310 & 0.2915 & 0.7948 & 0.1894 \\
Constant & $(0.16)$ & $(0.24)$ & $(0.50)$ & $(0.02)$ & $(0.67)$ \\
& 13.9071 & 11.6806 & 10.5766 & 18.3707 & 15.2676 \\
\hline adjust. $R^{2}$ & $(0.00)$ & $(0.00)$ & $(0.00)$ & $(0.00)$ & $(0.00)$ \\
\hline Nobs. & 0.0178 & 0.0009 & 0.0119 & 0.0017 & 0.0047 \\
\hline \hline
\end{tabular}

Least squares estimates regression of the Big 5 Traits on previous labor market participation, p-values in parenthesis. Dependent variable: Score of the personality trait. 
Table A6: Estimates of Wage Equation with Selectivity Correction

\begin{tabular}{|c|c|c|c|c|c|}
\hline$\overline{\text { Variable }}$ & without Big 5 & with Big 5 & $\begin{array}{l}\text { Big 5-Index } \\
2005\end{array}$ & without Education & $\begin{array}{l}\text { with Big } 5 \\
2007\end{array}$ \\
\hline EAST & $\begin{array}{c}-0.2332 \\
(0.00)\end{array}$ & $\begin{array}{c}-0.2310 \\
(0.00)\end{array}$ & $\begin{array}{c}-0.2335 \\
(0.00)\end{array}$ & $\begin{array}{c}-0.1821 \\
(0.00)\end{array}$ & $\begin{array}{c}-0.2415 \\
(0.00)\end{array}$ \\
\hline AGE & $\begin{array}{l}0.0181 \\
(0.07)\end{array}$ & $\begin{array}{l}0.0176 \\
(0.08)\end{array}$ & $\begin{array}{c}0.0185 \\
(0.06)\end{array}$ & $\begin{array}{c}0.0305 \\
(0.00)\end{array}$ & $\begin{array}{c}0.0096 \\
(0.41)\end{array}$ \\
\hline$A G E^{2} * 0.01$ & $\begin{array}{c}-0.0158 \\
(0.20)\end{array}$ & $\begin{array}{c}-0.0148 \\
(0.23)\end{array}$ & $\begin{array}{c}-0.0164 \\
(0.18)\end{array}$ & $\begin{array}{c}-0.0299 \\
(0.02)\end{array}$ & $\begin{array}{c}-0.0064 \\
(0.66)\end{array}$ \\
\hline GERMAN & $\begin{array}{c}0.1164 \\
(0.00)\end{array}$ & $\begin{array}{l}0.1107 \\
(0.00)\end{array}$ & $\begin{array}{c}0.1146 \\
(0.00)\end{array}$ & $\begin{array}{c}0.0919 \\
(0.02)\end{array}$ & $\begin{array}{c}0.1254 \\
(0.00)\end{array}$ \\
\hline MID_VOC & $\begin{array}{l}0.0383 \\
(0.17)\end{array}$ & $\begin{array}{c}0.0410 \\
(0.14)\end{array}$ & $\begin{array}{l}0.0387 \\
(0.17)\end{array}$ & & $\begin{array}{c}0.0149 \\
(0.66)\end{array}$ \\
\hline HIGH_VOC & $\begin{array}{c}0.1392 \\
(0.00)\end{array}$ & $\begin{array}{c}0.1404 \\
(0.00)\end{array}$ & $\begin{array}{c}0.1390 \\
(0.00)\end{array}$ & & $\begin{array}{l}0.1216 \\
(0.00)\end{array}$ \\
\hline HIGH_EDU & $\begin{array}{c}0.4273 \\
(0.00)\end{array}$ & $\begin{array}{l}0.4257 \\
(0.00)\end{array}$ & $\begin{array}{l}0.4270 \\
(0.00)\end{array}$ & & $\begin{array}{l}0.4090 \\
(0.00)\end{array}$ \\
\hline CONST & $\begin{array}{l}1.5613 \\
(0.00)\end{array}$ & $\begin{array}{l}1.569 \\
(0.00)\end{array}$ & $\begin{array}{l}1.6085 \\
(0.00)\end{array}$ & $\begin{array}{l}1.5771 \\
(0.00)\end{array}$ & $\begin{array}{l}1.7852 \\
(0.00)\end{array}$ \\
\hline EXT (2005) & & $\begin{array}{l}0.0212 \\
(0.02)\end{array}$ & & $\begin{array}{c}0.0054 \\
(0.61)\end{array}$ & $\begin{array}{l}0.0130 \\
(0.20)\end{array}$ \\
\hline AGREE (2005) & & $\begin{array}{c}-0.0175 \\
(0.05)\end{array}$ & & $\begin{array}{c}-0.0094 \\
(0.37)\end{array}$ & $\begin{array}{c}-0.0083 \\
(0.42)\end{array}$ \\
\hline CONSC (2005) & & $\begin{array}{c}-0.0230 \\
(0.04)\end{array}$ & & $\begin{array}{c}-0.0650 \\
(0.00)\end{array}$ & $\begin{array}{c}-0.0259 \\
(0.03)\end{array}$ \\
\hline NEU (2005) & & $\begin{array}{c}0.0010 \\
(0.90)\end{array}$ & & $\begin{array}{l}0.0007 \\
(0.94)\end{array}$ & $\begin{array}{c}-0.0072 \\
(0.44)\end{array}$ \\
\hline OPEN (2005) & & $\begin{array}{c}-0.0024 \\
(0.79)\end{array}$ & & $\begin{array}{l}0.0269 \\
(0.01)\end{array}$ & $\begin{array}{c}0.0104 \\
(0.32)\end{array}$ \\
\hline $\begin{array}{l}\text { Big Five Index } \\
(2005)\end{array}$ & & & $\begin{array}{c}-0.0068 \\
(0.43)\end{array}$ & & \\
\hline$\lambda$ & $\begin{array}{c}-0.1387 \\
(0.00)\end{array}$ & $\begin{array}{c}-0.1366 \\
(0.00)\end{array}$ & $\begin{array}{c}-0.1437 \\
(0.00)\end{array}$ & $\begin{array}{c}-0.3419 \\
(0.00)\end{array}$ & $\begin{array}{c}-0.1395 \\
(0.00)\end{array}$ \\
\hline Nobs. & 3,390 & 3,390 & 3,390 & 3,390 & 2,616 \\
\hline Log Lik & $-2,713$ & $-2,705$ & $-2,713$ & $-2,861$ & $-2,050$ \\
\hline
\end{tabular}

Heckit, p-values in parenthesis. Dependent variable: log hourly wages. Standardized values of the Big Five Traits. 


\section{B Figures}
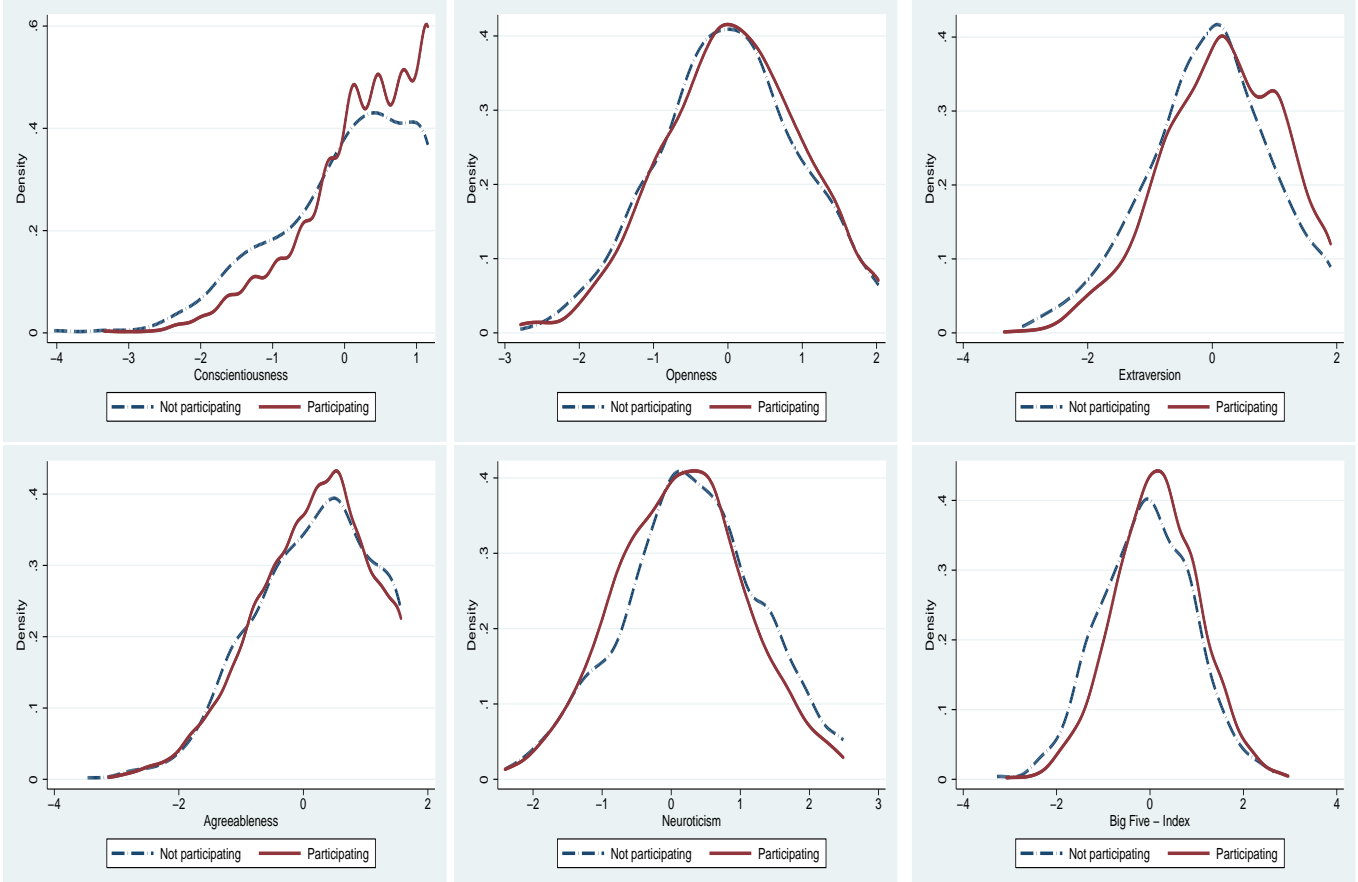

Figure B1: Distribution of the standardized Big Five Personality Traits in the Sample (SOEP, 2005) using a Gaussian Kernel with a bandwidth chosen by Silverman's rule of thumb.

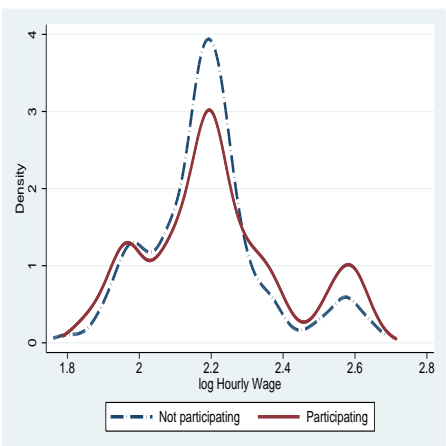

Figure B2: Distribution of the imputed hourly wages in the Sample (SOEP, 2005) using a Gaussian Kernel with a bandwidth chosen by Silverman's rule of thumb. 

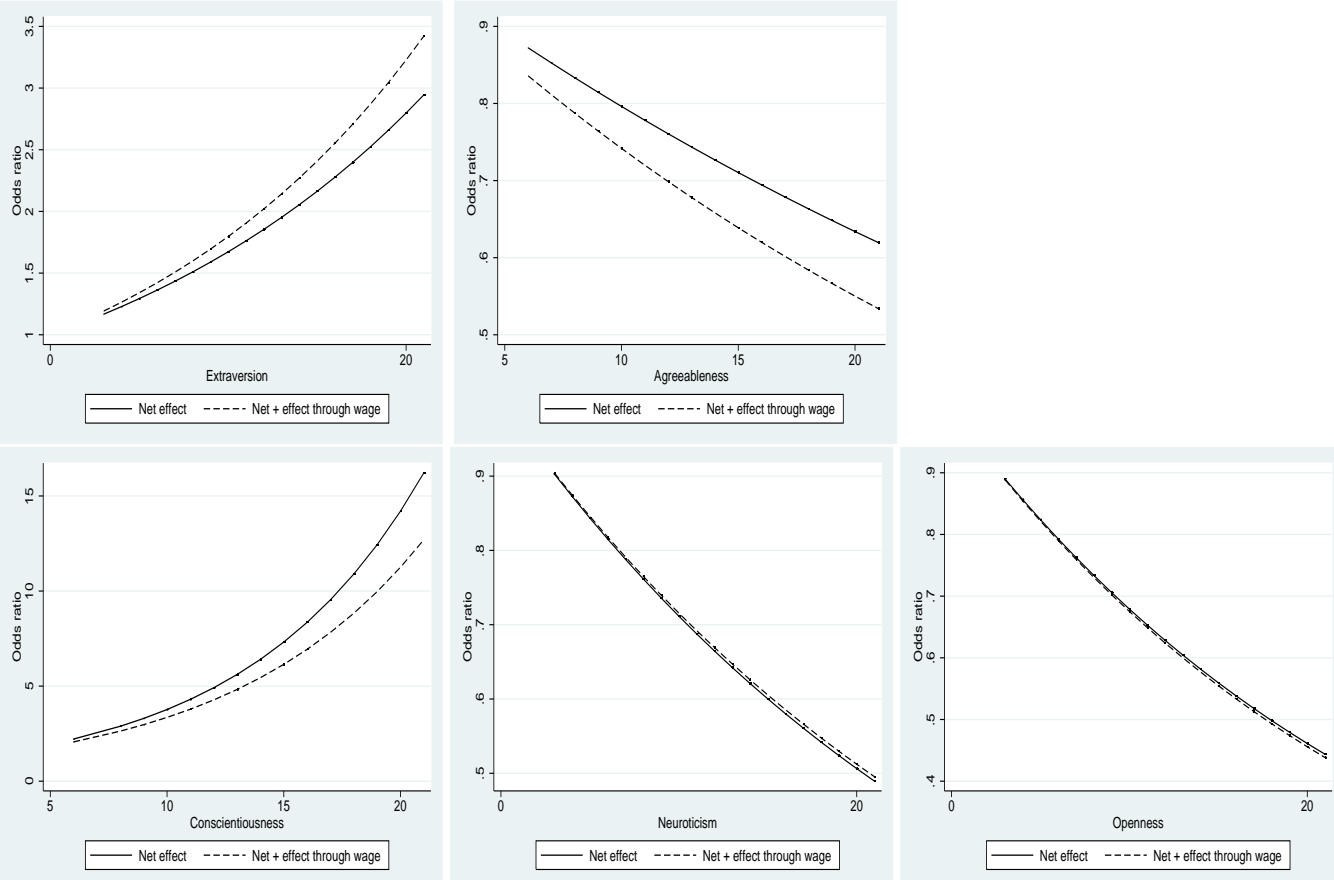

Figure B3: Direct and indirect effects of the Big Five Personality Traits on the participation probability (SOEP, 2005) 